\title{
Call For ACtion for a Healthier Planet INTRODUCING AGROFORESTRY
}

\author{
Veronika HONFY, Zsolt KESERŰ \\ National Agricultural Research and Innovation Centre, Forest Research Institute (NARIC FRI) \\ H-1027 Budapest, Frankel Leó út 1.
}

\begin{abstract}
Agroforestry is a key element amongst the tools fighting today's challenges, such as environmental issues, climate change, food safety and food security. It is a common agricultural practice in many countries of the developing world, whereas it has nearly faded away in most of the world's developed countries. In the past 40 years of agroforestry research it has been clarified that the role of trees in the landscape as well as in the farm scale is essential to maintain a healthy environment and it can be an economically viable practice in the long term, given careful planning. These complex agricultural systems address several Sustainable Development Goals, offer countless ecosystem services and are expected to get more attention and role in the future of world's agriculture. In the European Union, the Common Agricultural Policy firstly had played a negative effect on trees in the land, as it had encouraged farmers to eliminate them in order to qualify for subsidies, until in the last call it was encouraging farmers by subsidiring the establishment of agroforestry systems. Today's task is to reserve agroforestry systems which have remained (e.g., wood pastures, shelterbelts); conduct research to answer ecological, economical and management questions; establish demonstartion sites and disseminate knowledge on agroforestry systems. The Monpellier Declaration calls all stakeholders for action.
\end{abstract}

Keywords: agroforestry, trees outside forests, sustainable land use, climate change, Hungary

\section{INTRODUCTION}

\section{Agricultural deserts or thriving landscapes?}

Visualize a desert - sandy, rocky landscape, where are not many creatures livinghard to picture a life, especially for someone who was born in Europe. Now imagine a landscape, let it be Europe this time, in Hungary. An undelating area, no trees, no bushes, no roads, no buildings, only bright brownish bare soil stretched out till the horizon, exposed to the forces of nature, exposed to erosion and deflation, land degradation. We can call it cultural, or agricultural desert. Just like the natural desert, it also barely sustains life, but unlike the desert, it could be managed as a thriving ecosystem. It is our decision, our responsibility. It is our duty to manage our landcapes by applying the best of knowledge, and we do know that vanishing everything other than that one sole crop, working against life supporting natural processes (regeneration, succession) is not the sustainable way. We need healthy food, but grown in healthy landscapes, we need diversity, habitats and all of that we call ecosystem services. 
Agroforestry is an example of a more sustainable land use, and it is a key element amongst the tools fighting today's challenges, such as environmental issues, climate change, food safety and food security. In the past 40 years of agroforestry research it was clarified that the role of trees in the landscape as well as in the farm scale was essential to maintain a healthy environment and it can be an economically viable practice in the long term, given careful planning.

\section{DISCUSSION}

\section{Agroforestry}

Agroforestry means deliberate integration of woody perennials with crop production and/or animal husbandry for ecological and economical benefits. (Figure 1.)

It is a common agricultural practice in many countries of the developing world, whereas it has nearly faded away in most of the world's developed countries. One main reason globally is industrialized farming, where the goal is to acquire the highest yields with the highest profit possible, where trees are often seemed as obstacles of efficient machinery work. In the case of Hungary and Europe the Common Agricultural Policy added to this trend by encouraging farmers to eliminate the trees and shrubs on farms in order to qualify for maximum subsidies (SAPS - Single Area Payment Scheme).

\section{Figure 1.}

\section{Alley cropping - a type of agroforestry - experimental site at NARIC in Hungary. Hybrid poplars intercropped with triticale}

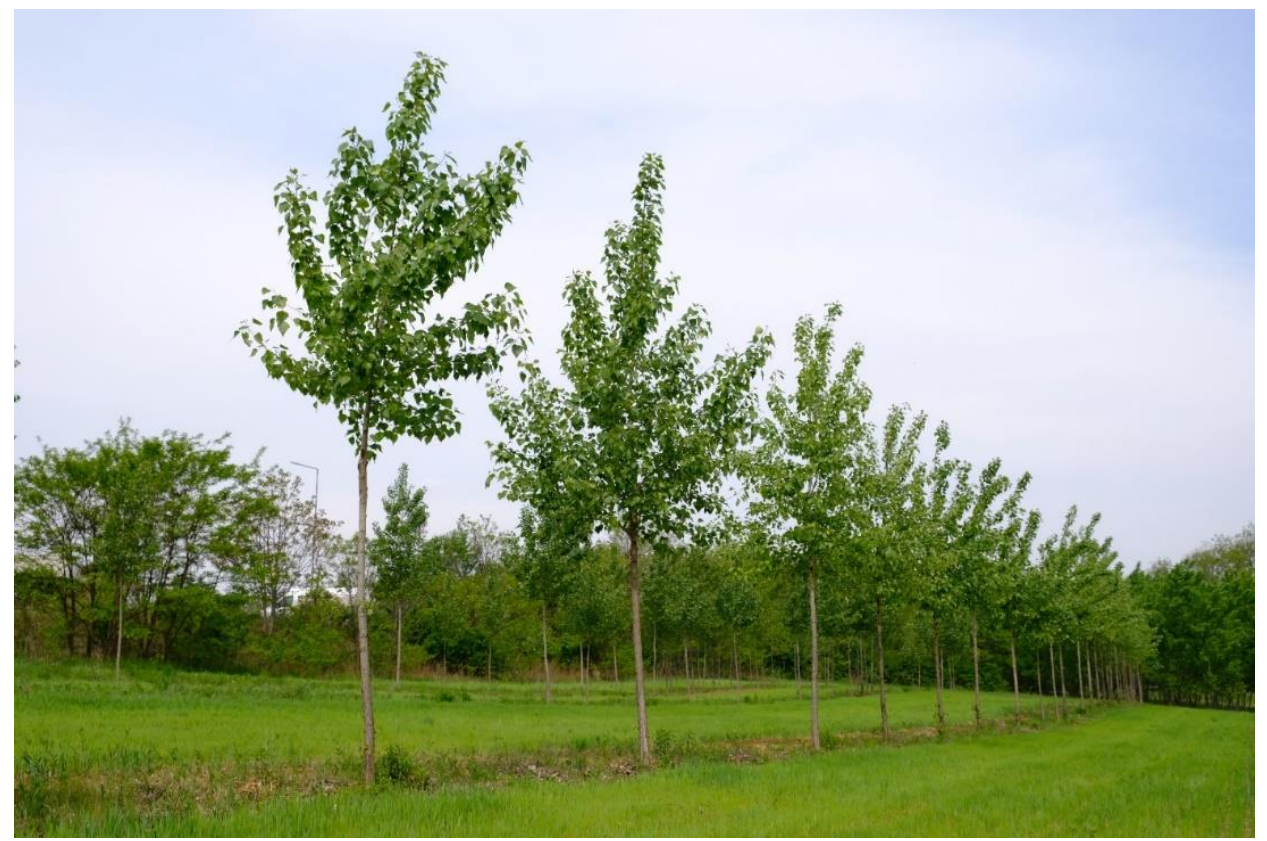


Some positive changes started in the last decade, and today agroforestry appears amongst the CAP where farmers can apply for subsidy for establishing agroforestry systems. This is the result of over 40 years of work of agroforestry scientists, and there is no doubt that climate change issues also highlight the importance of forests, trees, and agroforestry, amongst decision makers, politicians and even some farmers. We know that there is need to transform the farming systems, and we also know that the transition itself is costly. Therefore the outcome of the last Agroforestry Congress was a call for action (Table 1) for all stakeholders, phrased in the Montpellier Declaration (WCAS, 2019).

Table 1.

\section{Some key elements of the Montpellier Declaration, which calls on different stakeholders to urge agroforestry transition}

\begin{tabular}{|l|l|}
\hline \multicolumn{1}{|c|}{ Who? } & \multicolumn{1}{c|}{ What to do? } \\
\hline $\begin{array}{l}\text { Political decision- } \\
\text { makers }\end{array}$ & $\begin{array}{l}\text { engage in the process of deep transformation } \\
\text { accelerate transition, encourage the widespread adoption of } \\
\text { agroforestry through leadership, education and finance }\end{array}$ \\
\cline { 2 - 3 } $\begin{array}{l}\text { Private sector, } \\
\text { financial and } \\
\text { business leaders }\end{array}$ & $\begin{array}{l}\text { develop financial and investment models to mobilize the } \\
\text { capital resources necessary for the transformation of } \\
\text { agricultural systems around the world to agroforestry }\end{array}$ \\
\hline $\begin{array}{l}\text { Leaders of research } \\
\text { institutions }\end{array}$ & $\begin{array}{l}\text { prioritize the ongoing refinement of high-performance } \\
\text { agroforestry systems appropriate to all farm sizes, climatic } \\
\text { zones and income levels }\end{array}$ \\
\hline Researchers & \begin{tabular}{l} 
publication, call for action \\
\cline { 2 - 3 } Farmers, agroforestry \\
collaborate, implement research results in the field, establish \\
pilot farms, demonstration sites
\end{tabular} \\
\hline $\begin{array}{l}\text { advisory, mentoring - farmers most effectively learn from } \\
\text { each other }\end{array}$ \\
\hline
\end{tabular}

\section{Current state of Agroforestry - The $4^{\text {th }}$ World Congress}

It was the first time that the world congress on agroforestry systems was held in Europe. The 4th World Congress took place in Montpellier, France, in May 2019, following the congresses in the USA (2004), Kenya (2009) and India (2014). More than 1200 attendees were present from all around the world, from Indonesia to Colombia. The expenses of those 150 young researchers who arrived from developing countries was funded by the congress itself.

The aim of the congress was to contribute to advance agroforestry research, and build a bridge between science, society and politics. In the plenary sessions and more than 20 parallel sessions several popular and some under-represented topics were discussed, divided into four main categories: agroforestry and the world challenges, adoption of agroforestry, specific agroforestry systems and the biophysics of agroforestry. To mention a few of these topics: climate change, biodiversity, genetics, agroecology, land degradation and desertification in dry areas, social issues, 
businesses and finance, public policies, landscapes, modelling, mapping, practice, urban agroforestry, etc. There was also a section dedicated to the European Agroforestry Innovation Network (AFINET) and other themes which did not fit into the planned sections, but the topic of wood and wildlife management was not really presented. Altogether more than 300 presentations and 600 posters were presented in the congress. Looking at the participant list, it is visible that not only the number of researchers, but the number of state and business representatives was also remarkable, meaning that interest in agroforestry is growing. It is also worth mentioning that the International Union of Agroforestry (IUAF) has just been launched. The message of the congress was eventually summarized in the Montpellier Declaration.

\section{Montpellier Declaration}

The choice of the location of the world congress has its own message: Europe has joined the worldwide movement of agroforestry. Although agroforestry research started 20 years ago in Europe (40 years ago in the tropics), the awarness and acknowledgement of the scientific field between agricultural professionals, politicians and in the society had been awaited until the past few years in the old continent. While in the developing countries agroforestry systems thrive up to date due mainly to economic drawbacks, the developed countries are slowly sobering of environmental destruction and start to understand the benefits of land management combined with woody vegetations. The timing of the world congress was also a good choice considering that this was the time of forming the new CAP for the following period 2021-2027. A lot of organizations represented at the congress are lobbying and pushing agroforestry to gain more relevance - financially, professionally, and morally - and to get support for agroforestry systems. Thanks to the scientific work there is a vast amount of knowledge available in the field, yet there are still many questions to be answered, from good companion crops to financial matters, which need to be answered according to the actual configuration (site location, soil type, farmer, etc.) of the farm (Honfy and Keserü, 2019). The declaration calls for the research institutions to prioritize research on highly productive agroforestry systems in all climatic zones, all farm sizes and income levels. Due to the complexity of the topic exemplary cooperation is needed between different sectors to make sure that this sustainable land use system thrives again in farming practices and appear in the landscapes of developed countries, and also to make sure that it will be a living practice in developing countries just as it is today. Good examples and demonstration sites are necessities. It is one of the responsibilities of researchers that the message reaches the public, and eventually the research results are utilized on the farms. To apply agroforestry practices, mentoring, advisory and farmers' networks play a crucial role.

The participants of the congress agreed that inappropriate farming practices highly contribute to the severe loss of biodiversity reported by IPBES (Intergovernmental Science-Policy Platform on Biodiversity and Ecosystem Services). Agroforestry systems can contribute to treat this phenomenon, while sustaining food security. 
Agroforestry systems are usually profitable practices. What is costly, is the agroforestry transition itself. This transformation takes time and requires support. Therefore the declaration calls on decision makers - the public as well as the private sector -, business and financial leaders, and leading research institutions, private leadership, education and finance for the transition, to accelerate the adoption of agroforestry systems. The participants of the congress urge these stakeholders to deeply engage in the process, and calls on to promote the benefits of agroforestry amongst the world's landowners and land managers. Furthermore, they encourage the private sector to work out financial and investment models, which ensure capital for agricultural transition towards agroforestry worldwide.

The message is clear: „Make our planet treed again!” by planting the appropriate tree to the proper place.

\section{CONCLUSION}

Crop production, orchards, animal husbandry and forestry - all exposed to extreme meteorological events - are now facing even more challenges, including climate change and the continuously growing pressure from the society. Climate change mitigation and adaptation techniques now direct more attention to forests and trees outside forests, and to the important role of trees.

There are several reasons why it is worth considering seriously the diversification of the farm or land by introducing trees, either by farmers, communities, or municipalities. Agroforestry has become a movement. The 40 years of research, and politics seeking for solutions for global challenges seem to meet eventually at a point. (Honfy et al., 2019)

Today's task is to reserve agroforestry systems which have remained (e.g., wood pastures, shelterbelts); conduct research to answer ecological, economic and management questions; establish demonstration sites and disseminate knowledge on agroforestry systems. Eventually we need to work on the enabling atmosphere where farmers are encouraged to implement agroforestry systems, for a healthier living planet.

\section{ACKNOWLEDGEMENTS}

The publication of this paper is supported by the EFOP-3.6.2-16-2017-00018 "Produce together with the nature - agroforestry as a new outbreaking possibility" project.

\section{REFERENCES}

Honfy V., Borovics, A., Gyuricza, Cs., Keserű, Zs. (2019): Lendületben az agrárinnováció (In Hung.) Gödöllő, NAIK Könyvek. Agrárerdészet - Fák a mezőgazdaságban. 6-22. p. 
Honfy, V., Keserű, Zs. (2019): A 4. Agrárerdészeti Világkongresszus Üzenete (In Hung.) In: Tudományos eredmények a gyakorlatban. Alföldi Erdőkért Egyesület Kutatói Nap. Lakitelek, 2019.11.12. 195-197. p.

WCAS (2019): Montpellier Declaration. $4^{\text {th }}$ World Congress on Agroforestry Systems, Montpellier, France 20-22 May, 2019. [online]<URL: https://agroforestry2019.cirad.fr/content/download/4744/34532/version/2/ file/Montpellier_Declaration_24052019_VEng.pdf>

Corresponding author:

\section{Veronika HONFY}

National Agricultural Research and Innovation Centre

Forest Research Institute

H-1027 Frankel Leó út 1., Budapest, Hungary.

Phone: +36 70 197-5349

e-mail: honfy.veronika@erti.naik.hu 